\title{
Coronary heart disease risk factors in sub-Saharan Africa: studies in Tanzanian adolescents
}

\author{
Henry M Kitange, Andrew B M Swai, Gabriel Masuki, Peter M Kilima, \\ K George M M Alberti, Donald G McLarty
}

\begin{abstract}
Study Objective-To assess the level of cardiovascular risk factors in young people in sub-Saharan Africa living in rural and urban settings.
\end{abstract}

Design-Cross sectional survey of the population aged 15 to 19 years.

Setting-Eight rural Tanzanian villages in three regions, and two districts in Dar es Salaam.

Participants -664 males and 803 females in rural villages and 85 males and 121 females in the city. Response rates for total population were $74 \%$ to $94 \%$ in the rural areas and $60 \%$ in the city.

Measurements and results-Measurements included blood pressure, body mass index, serum lipids, and blood glucose concentrations (fasting and two hours after $75 \mathrm{~g}$ glucose). Blood pressure was slightly but significantly higher in young women than in young men $(115 / 67 \mathrm{mmHg}$ versus $113 / 65 \mathrm{mmHg}$ ) and increased significantly with age. Only $0.4 \%$ subjects had blood pressure greater than 140 and/or $90 \mathrm{mmHg}$. There were no urban-rural differences.

Body mass index was higher in females (mean (SD) $20.3(2 \cdot 8) \mathrm{kg} / \mathrm{m}^{2}$ ) than males $(18 \cdot 5$ $(2 \cdot 1))$. Overweight was found in only $0 \cdot 6 \%$ at age 15 years but $5 \cdot 4 \%$ at age 19 years. Serum cholesterol concentrations were low at $3.5 \mathrm{mmol} / 1$ in males and $3.7 \mathrm{mmol} / 1$ in females. Only $7 \%$ had values above $5 \cdot 2 \mathrm{mmol} / \mathrm{l}$. The highest concentrations were found in the city and in Kilimanjaro, the most prosperous rural region. Serum triglycerides were $1.0(0.5) \mathrm{mmol} / \mathrm{l}$ in males and $1.1(0 \cdot 5)$ $\mathrm{mmol} / \mathrm{l}$ in females, and were highest in the city dwellers. Diabetes was rare $(0 \cdot 28 \%$ males, $0 \cdot 12 \%$ females) but impaired glucose tolerance was present in $4.7 \%$ and $4 \cdot 1 \%$ respectively. Drinking alcohol was equally prevalent in males and females, reaching $30 \%$ at age 19 years. Only $0.4 \%$ of females smoked compared with $7 \cdot 3 \%$ of males. Smoking was commoner in rural areas that in the city.

Conclusions-Several risk factors for cardiovascular disease were found in Tanzanian adolescents, but levels were much lower than in studies reported from developed nations. The challenge is to maintain these low levels as the population becomes more urbanised and more affluent.

f Epidemiol Community Health 1993; 47: 303-307
Although coronary heart disease occurs mainly in middle age or later, the underlying atherosclerotic process may start early in life. In low incidence populations, the onset of atherosclerosis may possibly take place in adolescence or young adulthood. ${ }^{12}$ The major coronary heart disease risk factors and the behavioural patterns conducive to them also develop in youth. Moreover, it is well known that a 'tracking' effect exists, whereby risk factor levels of a child, unless controlled, tend to impose a higher risk in adulthood. ${ }^{3}$ Thus, there is some evidence, for example, that blood pressure in childhood is related to cardiovascular mortality in adulthood. ${ }^{4}$

Studies of cardiovascular disease risk factors in children and young people are necessary, as it is only when potential risk factors and health related behaviour are measured and analysed that specific intervention programmes may be designed, targets set, and outcomes evaluated. While many previous studies have assessed the prevalence of specific risk factors in selected populations, this is the first in which the prevalence of several major risk factors for cardiovascular disease has been assessed in young people in sub-Saharan African communities. Little information is available on the prevalence of coronary heart disease in rural sub-Saharan Africa, although anecdotally it is rare. We have recently reported that $10.5 \%$ of men and $21.1 \%$ of women in Tanzania over the age of 40 years showed possible or probable ischaemia on ECGs although none were symptomatic.

In the present study values of risk factors established as predictive of the development of coronary heart disease in adults have been used to compare the magnitude of these disorders in 15-19 year old teenagers in eight rural villages in three regions of Tanzania and in urban Dar es Salaam. This forms part of a larger study of risk factors across the total adult age range. ${ }^{5}$

\section{Subjects and methods}

BACKGROUND

Tanzania is a participating country in the World Health Organisation (WHO) Interhealth programme. ${ }^{6} 7$ Two districts, Morogoro rural district and Hai district in Morogoro and Kilimanjaro regions were selected as pilot districts. Six villages were selcted at random in the two regions for baseline studies to determine the prevalence rates of hypertension, diabetes, and other cardiovascular disease risk factors before the establishment of community based health care for subjects with chronic non-communicable diseases. A further village in Mara region was studied to investigate the relationship between diabetes 
and cyanide toxicity from the consumption of inadequately processed cassava. As a control, an eighth village in Kilimanjaro region where cassava is rarely eaten was also studied. To investigate differences between rural and urban populations, a community was studied in the Manzese area of Dar es Salaam city.

In four of the eight villages the total population aged 15 years and over numbered around 1000 . The entire adult population was therefore invited to participate. In the other four villages and in Manzese, Dar es Salaam random selection of 10 cell units was made to yield approximately 1000 subjects in each village. The response rate varied from 60 to $94 \%$. Of the total subjects 1669 were aged 15 to 19 years and are the subjects of this report. Some characteristics of the four regions and study population are shown in table I.

\section{METHODS \\ Blood tests}

Subjects were requested to report to the village school or dispensary after an overnight fast. Venous blood samples were obtained for measurement of serum total cholesterol and triglycerides, blood glucose, and haemoglobin. Serum was separated on site. It was stored at $-20^{\circ} \mathrm{C}$ and later shipped by air to the University of Newcastle upon Tyne, UK for analysis. Serum cholesterol and triglycerides were measured by standard enzymatic methods using a Cobas Bio centrifugal analyser. The interassay coefficients of variation were $2 \cdot 2 \%$ for cholesterol and $3 \cdot 2 \%$ for triglycerides.

After the fasting venous sample had been taken each subject was given $75 \mathrm{~g}$ glucose monohydrate in $300 \mathrm{ml}$ water. Venous blood was again drawn two hours later and placed in a flouride oxalate tube. Blood glucose was analysed immediately at the survey site using a Yellow Springs Instruments glucose analyser (Yellow Springs Instruments, Ohio, USA) powered by a Honda EM 650 generator. An aliquot of every 5 th sample was kept frozen at $-20^{\circ} \mathrm{C}$ and later analysed by a hexokinase fluoremetric method using a Cobas Bio Centrifugal analyser (Roche products Ltd, Welwyn Garden City, UK) at the University of Newcastle upon Tyne. The linear correlation coefficient between the survey site and the Newcastle upon Tyne laboratory was 0.98 and the

Table I Characteristics of the study population

\begin{tabular}{|c|c|c|c|c|}
\hline & \multirow{2}{*}{$\frac{\text { Urban }}{\text { Dar es Salaam }}$} & \multicolumn{3}{|l|}{ Rural } \\
\hline & & Kilimanjaro & Morogoro & Mara \\
\hline $\begin{array}{l}\text { No surveyed }(\% \text { total })^{\star} \\
\text { Male } \\
\text { Female } \\
\text { Response rate for whole area }(\%) \\
\text { Major tribal group } \\
\text { Major staple diet }\end{array}$ & $\begin{array}{l}85(13 \cdot 5) \\
121(14 \cdot 6) \\
60 \\
\text { Mixed } \\
\text { Rice and } \\
\text { maize }\end{array}$ & $\begin{array}{l}266(15 \cdot 5) \\
429(15 \cdot 6) \\
94 \\
\text { Chagga } \\
\text { Bananas }\end{array}$ & $\begin{array}{l}246(17 \cdot 0) \\
255(15 \cdot 6) \\
84 \\
\text { Luguru } \\
\text { Maize, rice, } \\
\text { and millet }\end{array}$ & $\begin{array}{l}152(31 \cdot 4) \\
119(19.9) \\
74 \\
\text { Jaluo } \\
\text { Millet, cassava }\end{array}$ \\
\hline
\end{tabular}

«Total=total number of subjects (all ages) surveyed in the particular area slope did not differ significantly from 1 with an intercept at less than $0.1 \mathrm{mmol} / \mathrm{l}$. The coefficient of variation for measurements on site was $1 \cdot 8 \%$. Haemoglobin was measured using a Cyanox digital haemoglobinometer (Buffalo Medical Specialties, Buffalo, USA).

\section{Blood pressure}

Blood pressure (phase 1 and V) was measured twice with a mecury sphygmomanometer, using the right arm and with the subject seated. The mean of the two readings was used.

\section{Cigarette smoking}

Subjects were asked if they smoked, at the time of the survey or in the past. If they were current of past smokers, the number of cigarettes smoked per day and duration of smoking was recorded.

\section{Body mass index}

Weight and height were measured, without shoes or coats, using a beam balance stadiometer, and body mass index (BMI) calculated from weight (kg) over height ${ }^{2}\left(\mathrm{~m}^{2}\right)$,

\section{History}

Questionnaires were completed for all subjects on which were recorded the patients age, sex, alcohol intake, chest pain, and past history of cardiac or cerebrovascular disease, and a number of other symptoms and signs.

\section{DEFINITIONS AND DATA ANALYSIS}

Serum total cholesterol

Concentrations were divided into two groups: high $>=5 \cdot 2$ and normal $<5.2 \mathrm{mmol} / \mathrm{l}$.

\section{Serum triglyceride}

Concentrations were divided into two groups: high, $>=1.7 \mathrm{mmol} / 1$ and normal, $<1.7 \mathrm{mmol} / \mathrm{l}$.

\section{Blood pressure}

Values were divided into three groups: normal blood pressure $<140 / 90 \mathrm{mmHg}$, intermediate blood pressure (borderline hypertension) $>=140$ and/or $>=90<160 / 95$, and high blood pressure (hypertension $>=160$ and/or $>=95 \mathrm{mmHg}$.

\section{Smoking}

Subjects were grouped into two-those who were current smokers and those who had never smoked or had not smoked for the previous six months.

\section{Glucose tolerance}

This was classified according to the 1985 WHO criteria for epidemiological studies-that is two hour venous whole blood glucose concentrations $>=10 \mathrm{mmol} / \mathrm{l}$ for diabtetes, $>=6.7 \mathrm{mmol} / 1$ $<10 \mathrm{mmol} / 1$ for impaired glucose tolerane (IGT), and normal, $<6.7 \mathrm{mmol} / 1$.
Table II Mean values (SD) of cardiovascular risk factors of the adolescent population by gender

\begin{tabular}{|c|c|c|c|c|c|c|c|}
\hline \multirow[b]{2}{*}{ Variable } & \multicolumn{3}{|l|}{ Male } & \multicolumn{4}{|c|}{ Female } \\
\hline & $\overline{N o}$ & Mean & $(S D)$ & No & Mean & $(S D)$ & $p$ \\
\hline $\begin{array}{l}\text { Systolic blood pressure }(\mathrm{mmHg}) \\
\text { Diastolic blood pressure }(\mathrm{mmHg}) \\
\text { Serum cholesterol }(\mathrm{mmol} / \mathrm{l}) \\
\text { Serum triglycerides }\left(\mathrm{mmol}^{2}\right) \\
\text { Body mass index }\left(\mathrm{kg} / \mathrm{m}^{2}\right) \\
\text { Fasting blood glucose } \\
\text { 2-hour blood glucose }(\mathrm{mmol} / \mathrm{l}) \\
\text { Age (y) }\end{array}$ & $\begin{array}{l}747 \\
747 \\
617 \\
621 \\
748 \\
740 \\
725 \\
749\end{array}$ & $\begin{array}{c}113 \\
65 \\
3 \cdot 5 \\
0 \cdot 99 \\
18 \cdot 6 \\
4 \cdot 2 \\
4 \cdot 6 \\
16 \cdot 7\end{array}$ & $\begin{array}{r}(12 \cdot 7) \\
(9 \cdot 7) \\
(1 \cdot 0) \\
(0 \cdot 5) \\
(2 \cdot 3) \\
(0 \cdot 7) \\
(1 \cdot 1) \\
(1 \cdot 4)\end{array}$ & $\begin{array}{l}923 \\
923 \\
792 \\
792 \\
922 \\
916 \\
915 \\
924\end{array}$ & $\begin{array}{c}115 \\
67 \\
3 \cdot 7 \\
1 \cdot 06 \\
20 \cdot 2 \\
4 \cdot 2 \\
4 \cdot 7 \\
16 \cdot 8\end{array}$ & $\begin{array}{l}(12 \cdot 1) \\
(9 \cdot 3) \\
(1 \cdot 1) \\
(0 \cdot 5) \\
(2 \cdot 7) \\
(0 \cdot 6) \\
(1 \cdot 1) \\
(1 \cdot 5)\end{array}$ & $\begin{array}{l}0.001 \\
0.001 \\
0.001 \\
0.063 \\
0.001 \\
\text { NS } \\
0.074 \\
-\end{array}$ \\
\hline
\end{tabular}


Body mass index (BMI)

The BMI was defined as weight $(\mathrm{kg})$ divided by the square of height $\left(\mathrm{m}^{2}\right)$. Patients with BMI below 20 were regarded as being underweight, those with BMI values of 20-25 as normal weight, and those with BMI values over 25 as overweight.

\section{Statistics}

Data were analysed using the Statistical Package for the Social Sciences (SPSS/PC+) for the IBM/AT microcomputer. Proportions were compared by the standard test for differences between two proportions. Results are presented as mean (SD) unless otherwise stated. Analysis of variance was used to compare group means.

\section{Results}

Table II shows mean values of measured risk factors by gender, table III percentile distributions, and table IV the values by area studied.

Overall, females had slightly but significantly higher mean (SD) systolic and diastolic blood pressures of 115 (12)/67 (9) $\mathrm{mmHg}$ compared with 113 (13)/65 (10) $\mathrm{mmHg}$ for males $(\mathrm{p}<0.001)$ (Table II). Only six $(0.4 \%)$ subjects (four females and two males) had both diastolic

Table III Centile distribution of cardiovascular risk factors in adolescents by gender

\begin{tabular}{|c|c|c|c|c|c|c|}
\hline & \multicolumn{6}{|c|}{ Centiles } \\
\hline & 10 & 20 & 50 & 80 & 90 & 95 \\
\hline \multicolumn{7}{|l|}{ Males: } \\
\hline Systolic blood pressure ( $\mathrm{mmHg}$ ) & 99 & 104 & 114 & 124 & 130 & 135 \\
\hline Diastolic blood pressure $(\mathrm{mmHg})$ & 54 & 59 & 66 & 74 & 79 & 81 \\
\hline Serum cholesterol $(\mathrm{mmol} / \mathrm{l})$ & $2 \cdot 4$ & $2 \cdot 8$ & $3 \cdot 5$ & $4 \cdot 3$ & $4 \cdot 9$ & $5 \cdot 5$ \\
\hline Serum triglycerides $(\mathrm{mmol} / \mathrm{l})$ & $0 \cdot 6$ & $0 \cdot 7$ & 0.9 & $1 \cdot 3$ & $1 \cdot 6$ & 1.9 \\
\hline Fasting blood glucose $(\mathrm{mmol} / \mathrm{l})$ & $3 \cdot 4$ & $3 \cdot 7$ & $4 \cdot 2$ & $4 \cdot 7$ & $5 \cdot 0$ & $5 \cdot 3$ \\
\hline Two hour blood glucose $(\mathrm{mmol} / \mathrm{l})$ & $3 \cdot 4$ & $3 \cdot 8$ & $4 \cdot 6$ & $5 \cdot 5$ & $6 \cdot 0$ & $6 \cdot 6$ \\
\hline Body mass index $\left(\mathrm{kg} / \mathrm{m}^{2}\right)$ & $16 \cdot 2$ & $17 \cdot 2$ & $19 \cdot 4$ & $21 \cdot 5$ & $22 \cdot 8$ & $23 \cdot 9$ \\
\hline \multicolumn{7}{|l|}{ Females: } \\
\hline Systolic blood pressure $(\mathrm{mmHg})$ & 100 & 105 & 115 & 126 & 130 & 135 \\
\hline Diastolic blood pressure (mmHg) & 56 & 60 & 68 & 75 & 80 & 82 \\
\hline Serum cholesterol $(\mathrm{mmol} / \mathrm{l})$ & $2 \cdot 6$ & $3 \cdot 0$ & $3 \cdot 6$ & $4 \cdot 5$ & $5 \cdot 1$ & $5 \cdot 7$ \\
\hline Serum triglycerides $(\mathrm{mmol} / \mathrm{l})$ & $0 \cdot 6$ & $0 \cdot 7$ & $1 \cdot 0$ & $1 \cdot 4$ & $1 \cdot 6$ & 1.9 \\
\hline Fasting blood glucose $(\mathrm{mmol} / \mathrm{l})$ & $3 \cdot 4$ & $3 \cdot 7$ & $4 \cdot 2$ & $4 \cdot 7$ & $4 \cdot 9$ & $5 \cdot 2$ \\
\hline Two hour blood glucose $(\mathrm{mmol} / \mathrm{l})$ & $3 \cdot 4$ & $3 \cdot 9$ & $4 \cdot 7$ & $5 \cdot 5$ & $6 \cdot 0$ & $6 \cdot 5$ \\
\hline Body mass index $\left(\mathrm{kg} / \mathrm{m}^{2}\right)$ & $16 \cdot 7$ & $17 \cdot 9$ & $20 \cdot 3$ & $22 \cdot 4$ & 23.6 & $24 \cdot 9$ \\
\hline
\end{tabular}

Table IV Mean and prevalences of cardiovascular risk factors in adolescent population by region

\begin{tabular}{|c|c|c|c|c|c|c|c|c|c|}
\hline & \multicolumn{4}{|c|}{ Dar es Salaam Kilimanjaro } & \multicolumn{2}{|l|}{ Mara } & \multicolumn{2}{|c|}{ Morogoro } & $p$ \\
\hline \multicolumn{10}{|c|}{ Blood pressure $(\mathrm{mmHg})$ : } \\
\hline Systolic & \multirow{2}{*}{\multicolumn{2}{|c|}{$\begin{array}{r}113(11 \cdot 6) \\
67(8 \cdot 1)\end{array}$}} & \multirow{2}{*}{\multicolumn{2}{|c|}{$\begin{array}{r}114(12 \cdot 8) \\
66 \quad(9.9)\end{array}$}} & $116(12)-3)$ & 2.9) & \multirow{2}{*}{\multicolumn{2}{|c|}{$\begin{array}{r}114(11 \cdot 7) \\
69 \quad(8 \cdot 8)\end{array}$}} & 0.0085 \\
\hline Diastolic & & & & & 62( & $(9 \cdot 7)$ & & & 0.0001 \\
\hline $\begin{array}{l}\text { No } \\
\text { Borderline hynertension }\end{array}$ & \multicolumn{2}{|c|}{206} & \multicolumn{2}{|c|}{694} & 268 & & \multicolumn{3}{|c|}{501} \\
\hline $\begin{array}{l}\text { Borderline hypertension } \\
(\%)\end{array}$ & \multirow{2}{*}{\multicolumn{2}{|c|}{$\begin{array}{l}2 \cdot 0 \\
0\end{array}$}} & \multicolumn{2}{|l|}{$3 \cdot 3$} & $4 \cdot 5$ & & \multicolumn{2}{|l|}{$2 \cdot 6$} & NS \\
\hline Hypertension (\%) & & & $0 \cdot 1$ & & 0.4 & & $0 \cdot 2$ & & 0.3120 \\
\hline \multicolumn{10}{|l|}{ Serum cholesterol } \\
\hline$(\mathrm{mmol} / \mathrm{l})$ & \multirow{2}{*}{\multicolumn{2}{|c|}{$\begin{array}{cc}3 \cdot 8 & (1 \cdot 1) \\
179 & \end{array}$}} & \multirow{2}{*}{\multicolumn{2}{|c|}{$\begin{array}{c}3 \cdot 8 \\
576\end{array}$}} & $3 \cdot 7$ & $(0 \cdot 9)$ & \multirow{2}{*}{\multicolumn{3}{|c|}{$\begin{array}{cc}3 \cdot 3 & (1 \cdot 0)\end{array}$}} \\
\hline No & & & & & 239 & & & & \\
\hline $\begin{array}{l}>=5.2 \mathrm{mmol} / 1(\%) \\
\text { Serum triglyceride }\end{array}$ & \multicolumn{2}{|l|}{$9 \cdot 5$} & \multirow{2}{*}{\multicolumn{2}{|c|}{$9 \cdot 4$}} & $4 \cdot 2$ & & \multicolumn{2}{|l|}{3.9} & 0.001 \\
\hline \multicolumn{8}{|l|}{ Serum triglyceride } & & \\
\hline $\begin{array}{l}(\mathrm{mmol} / \mathrm{l}): \\
\text { No }\end{array}$ & \multicolumn{2}{|c|}{$1 \cdot 12(0 \cdot 65)$} & \multicolumn{2}{|c|}{$0.98(0.42)$} & 1.02 & $2(0.47)$ & \multirow{2}{*}{\multicolumn{2}{|c|}{413}} & 0.0006 \\
\hline$>=1.7 \mathrm{mmol} / 1(\%)$ & \multirow{2}{*}{\multicolumn{2}{|c|}{$9 \cdot 5$}} & 577 & & 243 & & & & \\
\hline \multicolumn{4}{|l|}{ Blood glucose $(\mathrm{mmol} / \mathrm{l})$ : } & & & & \multicolumn{2}{|c|}{$6 \cdot 8$} & \\
\hline Fasting & $4 \cdot 4$ & $(0 \cdot 6)$ & $4 \cdot 1$ & $(0 \cdot 6)$ & $4 \cdot 6$ & $\cdot(0 \cdot 7)$ & & & 0.0001 \\
\hline 2 hour & \multirow{3}{*}{\multicolumn{2}{|c|}{205}} & $4 \cdot 5$ & $(1 \cdot 1)$ & $5 \cdot 0$ & $(0 \cdot 8)$ & $4 \cdot 7$ & $(1 \cdot 2)$ & 0.0001 \\
\hline $\begin{array}{l}\text { No } \\
\text { Impaired glucose }\end{array}$ & & & \multirow{2}{*}{\multicolumn{2}{|c|}{687}} & 265 & & 498 & & \\
\hline $\begin{array}{l}\text { Impaired glucose } \\
\text { tolerance }(\%)\end{array}$ & & & & & $4 \cdot 1$ & & $5 \cdot 2$ & & \\
\hline Diabetes (\%) & 0 & & $0 \cdot 3$ & & 0 & & $0 \cdot 2$ & & $0 \cdot 0890$ \\
\hline Body mass index $\left(\mathrm{kg} / \mathrm{m}^{2}\right)$ : & $: 20 \cdot 8$ & $(2 \cdot 9)$ & $19 \cdot 3$ & $(2 \cdot 6)$ & $19 \cdot 5$ & $(2 \cdot 8)$ & $19 \cdot 2$ & $(2 \cdot 4)$ & 0.0001 \\
\hline No & 206 & & 692 & & 271 & & 501 & & \\
\hline Underweight (\%) & $41 \cdot 5$ & & $60 \cdot 5$ & & $58 \cdot 3$ & & 62.5 & & 0.001 \\
\hline Overweight $(\%)$ & $6 \cdot 8$ & & $2 \cdot 0$ & & 3.0 & & $2 \cdot 0$ & & 0.0018 \\
\hline Smoking $(\%)$ : & 1.9 & & $5 \cdot 6$ & & 0 & & $4 \cdot 4$ & & 0.0027 \\
\hline No & 211 & & 693 & & 271 & & & & \\
\hline Alcohol (\%): & $13 \cdot 1$ & & $45 \cdot 8$ & & 0.4 & & $9 \cdot 4$ & & $0 \cdot 0001$ \\
\hline No & 207 & & 695 & & 271 & & 500 & & \\
\hline
\end{tabular}

p, significance of difference between groups.

Results are mean (SD) or \%. and systolic blood pressures above 140 and $90 \mathrm{mmHg}$ respectively. The mean systolic blood pressure in males increased from 107 (12) $\mathrm{mmHg}$ at age 15 years to 119 (11) $\mathrm{mmHg}$ at age 19 ( $p=0.07$ for trend). Females showed no significant difference in systolic blood pressure with values of 112 (13) $\mathrm{mmHg}$ at age 15 years and $116(12)$ at age 19 years. Mean diastolic blood pressure increased from $62(10) \mathrm{mmHg}$ at age 15 years in males to $69(8) \mathrm{mmHg}$ at age $19(\mathrm{p}=0.009)$ and from $66(10) \mathrm{mmHg}$ at age 15 years to $68 \mathrm{mmHg}$ at age 19 years $(p=0.05)$ in females.

The mean total serum cholesterol concentration was $3.5(1.0) \mathrm{mmol} / \mathrm{l}$ for males and 3.7 $(1 \cdot 1) \mathrm{mmol} / \mathrm{l}$ for females $(\mathrm{p}<0 \cdot 001)$. The mean total serum cholesterol did not change with age. About $7 \%$ of the subjects had a mean total serum cholesterol of $>=5.2 \mathrm{mmol} / 1$; males $5.5 \%$ and females $8.0 \%(p=0 \cdot 070)$. Dar es Salaam (urban) and Kilimanjaro (relatively more prosperous) regions had the highest prevalence $(9.5 \%$ and $9 \cdot 4 \%$ respectively) of raised total serum cholesterol $(>=5 \cdot 2 \mathrm{mmol} / \mathrm{l})$ compared to Mara $(4 \cdot 2 \%)$ and Morogoro (3.9\%).

Mean serum triglycerides for males were 1.0 $(0.5) \mathrm{mmol} / \mathrm{l}$ compared with $1 \cdot 1(0 \cdot 5)$ for females $(p=0.006)$. High serum triglycerides $(>1.7$ $\mathrm{mmol} / \mathrm{l}$ ) were detected in $6.3 \%$ of the males and $7 \cdot 2 \%$ in females (NS). The prevalence of raised serum triglyceride values was greatest in Dar es Salaam $(9 \cdot 4 \%)$ followed by Mara $(7 \cdot 8 \%)$, Morogoro (6.8\%), and Kilimanjaro (5.6\%) (Table IV). No age trend was noticed in the mean serum triglycerides.

Mean blood glucose values did not differ significantly between males and females and there was not trend with age. Mara region adolescents had the highest mean fasting blood glucose (4.6 $(0 \cdot 7) \mathrm{mmol} / \mathrm{l})$ and Kilimanjaro and Morogoro the lowest $(4 \cdot 1 \mathrm{mmol} / \mathrm{l})$, whereas Dar es Salaam had a mean of $4 \cdot 4 \mathrm{mmol} / 1$.

Subjects from Kilimanjaro region tended to show the lowest mean two hour blood glucose concentration $4.5(1.06) \mathrm{mmol} / \mathrm{l}$, compared with Dar es Salaam 5.0 $(1.04) \mathrm{mmol} / \mathrm{l}$, Mara 5.0 $(0 \cdot 85) \mathrm{mmol} / \mathrm{l}$, and Morogoro $4 \cdot 7(1 \cdot 18) \mathrm{mmol} / \mathrm{l}$ $(p=0.0001)$. The prevalence of diabetes mellitus was $0.28 \%$ and impaired glucose tolerance was present in $4.7 \%$ males compared with values of $0 \cdot 12 \%$ and $4.1 \%$ respectively for females (NS). Dar es Salaam adolescents had the highest IGT prevalence rate $(6.5 \%)$ compared with Morogoro $(5 \cdot 2 \%)$, Mara $(4 \cdot 1 \%)$, and Kilimanjaro $(2 \cdot 7 \%)$. The IGT rate increased from $2.4 \%$ at age 15 years to $6 \cdot 2 \%$ at the age of 19 years $(p=0.001)$.

The mean (SD) body mass index (BMI) was nigher for females $(20 \cdot 3(2 \cdot 8))$ than males $(18.5$ $(2 \cdot 1))(\mathrm{p}=0.001)$. The body mass index increased with age from $18 \cdot 2$ at age 15 to $21 \cdot 1$ at age 19 $(p<0.001)$. Only $0.4 \%$ of the males were overweight compared with $4.6 \%$ of the females.

There was no significant difference between the prevalence of drinking alcohol among males and females $(25.4 \%$ for males and $21.9 \%$ for females). Drinking increased with age, however, from $18.7 \%$ at 15 years to $30.2 \%$ at age 19 years $(p=0.008)$. Kilimanjaro region had the highest prevalence of drinkers (45.8\%) compared with Dar es Salaam (13.0\%), Morogoro (9.4\%), and Mara $(0.4 \%)(p=0.0001)$. 
Among males, $8 \cdot 3 \%$ were smokers compared with $0.4 \%$ of the females. The prevalence of smoking increased from $1 \cdot 1 \%$ at age 15 years to $7 \cdot 3 \%$ at the age of 19 years $(p=0 \cdot 0016)$. None of those from Mara region smoked, whereas $1.9 \%$ of those in Dar es Salaam, $4.4 \%$ in Morogoro, and $5.6 \%$ in Kilimanjaro region were smokers $\mathrm{p}=0 \cdot 0024)$.

\section{Discussion}

The striking finding in this study was the number of adolescents who already seemed to be at risk for the development of coronary heart disease. This conclusion was based on criteria which have been established for adults from data gathered from prospective studies. In adults there is a direct relationship of risk of coronary heart disease to the level of serum cholesterol, blood pressure, and cigarette smoking. ${ }^{8}$ In the course of individual development from childhood through youth to adulthood, serum cholesterol and systolic blood pressure tend to remain at similar levels relative to those of other members of the same population. ${ }^{9}$ Thus, it would seem appropriate to identify and consider at risk those children whose serum cholesterol concentration and blood pressure are at levels established in adults as predictive of the development of early occlusive atheromatous disease.

The serum cholesterol concentration that constitutes a risk factor for coronary heart disease in adults has long been debatable. The Framingham study indicated a continuous increase of risk for coronary heart disease with serum cholesterol values above $4.65 \mathrm{mmol} / \mathrm{l}(180 \mathrm{mg} / \mathrm{dl}) .{ }^{10} \mathrm{In}$ countries in which the incidence of coronary heart disease is very low, the mean serum cholesterol values of adults are in the 3.62 to $4.14 \mathrm{mmol} / 1$ $(140-160 \mathrm{mg} / \mathrm{dl})$ range $\mathrm{e}^{11} 12$ but there is still a continuum of risk. ${ }^{12}$ Futhermore, in experimental animals atherosclerosis does not develop when serum cholesterol are below $4.65 \mathrm{mmol} / \mathrm{l}$ $(180 \mathrm{mg} / \mathrm{dl}) .{ }^{10}$ In young people (ages $5-18$ years) the ideal mean is stated to be $2.85 \mathrm{mmol} / \mathrm{l}$ $(110 \mathrm{mg} / \mathrm{dl})$ and the feasible mean $3.62 \mathrm{mmol} / \mathrm{l}$ $(140 \mathrm{mg} / \mathrm{dl}) .{ }^{8}$ Our study showed the mean serum total cholesterol to be $3.46 \mathrm{mmol} / \mathrm{l}(134 \mathrm{mg} / \mathrm{dl})$ in young men and $3.74 \mathrm{mmol} / \mathrm{l}(144 \mathrm{mg} / \mathrm{dl})$ in young women. There is need for health promotion to keep the population cholesterol values at such acceptable rates in Tanzania.

Kannel and Dawber ${ }^{13}$ have suggested an upper limit for normal blood pressure of $140 / 90 \mathrm{mmHg}$ which seems very high for adolescents. ${ }^{14}$ Only six $(0.4 \%)$ of our subjects had both systolic and diastolic blood pressure above 140 and $90 \mathrm{mmHg}$. In longitudinal studies it has been shown that adolescents with a high blood pressure maintain the high pressure later in life..$^{15} 16$ Therefore it may be of importance to follow these persons who may eventually need treatment. In general, however, blood pressure was at safe levels in most adolescents. Levels were slightly higher than in Zambian 16 year olds. ${ }^{17}$ As here they found a modest increase in females compared with males. Values were, however, lower than in Nigeria. ${ }^{18}$

The prevalence of regular cigarette smoking varies considerably among children and young people by age, gender, and country. ${ }^{3}$ The prevalence of smoking among adolescents in our study is lower than in any other country in a WHO report in which India had the lowest prevalence of $10 \%$ in males age $15-20$ years and $4 \%$ in females. ${ }^{3}$ Figures were $40 \%$ or more in most European countries. In our study the prevalence of smoking increased from $1 \cdot 1 \%$ at age of 15 years to $7 \cdot 3 \%$ at age 19 , hence the need for intensified education and primary prevention before the age of 15 years.

In adults, alcohol consumption has been shown to influence blood pressure levels. The prevalence of alcohol drinking in our study increased from $18 \cdot 7 \%$ at age 15 to $30 \cdot 2 \%$ at the age of 19 . Kilimanjaro region which is relatively more prosperous, had the highest prevalence of alcohol drinkers $(45 \cdot 8 \%)$. Mara region whose main religious groups are the Seventh Day Adventists had the lowest prevalence of drinkers (and smokers) indicating importance of religious beliefs in prevention of certain risk factors of cardiovascular disease.

It is well recognised that diabetes mellitus is associated with an increased risk of coronary heart disease. Females with diabetes experience coronary heart disease at higher rates than nondiabetic females. Men with diabetes experience coronary heart disease at twice the rate of men without diabetes. ${ }^{19}$ It is not known whether blood glucose or diabetes is a risk factor for coronary heart disease in blacks, although the frequency of coronary heart disease as a contributing cause of death suggests that it is. ${ }^{20} \mathrm{~A}$ study of 198 diabetic African patients in Nairobi, Kenya showed that 30 had anginal pain, and 24 of these and had ECG abnormalities consistent with coronary heart diseae (ST depression or T inversion or both). ${ }^{21}$ The prevalence of diabetes and impaired glucose tolerance was low in our study, as would be expected in a country where type 1 diabetes is infrequent ${ }^{22}$ and type 2 diabetes is also uncommon. ${ }^{23}$ On the other hand, there was already a significant prevalence of IGT. Some of this may have been transient due to alarm at venepuncture, ${ }^{24}$ but nonetheless these IGT rates at this young age indicate a potential for later diabetes if the lifestyle becomes more westernised.

It is pertinent to compare risk factor levels with those from westernised societies. An equivalent study from Denmark was published recently based on a relatively small number (293) of 16-19 year olds. ${ }^{14}$ Mean values for blood pressure were markedly higher in Danish boys (125/73 mmHg $v$ $113 / 65$ ) but were more similar in girls. Not surprisingly, cholesterol values were also higher in the Danes $(4.1 \mathrm{mmol} / 1$ in males, $4.5 \mathrm{mmol} / 1$ in females) although triglycerides were lower in Denmark. Presumably this reflects a response to the very high carbohydrate diet in Tanzania. Smoking was also more prevalent in Denmark at 25 to $30 \%$, although less than in the 1970 s. Blood glucose values were not reported in the Danish study. The body mass index calculated from the Danish data was also higher than in Tanzania. Similar differences were found with American children in the Muscatine study. ${ }^{9}$ In both Denmark and the USA many more values were in the abnormal range than in Tanzania.

Thus, the overall prevalence of the major cardiovascular disease risk factors (raised blood 
pressure, dyslipidaemia, abnormal glucose tolerance, and overweight) was gratifyingly low. Among the reasons for this are undoubtedly high levels of exercise, high unrefined carbohydrate diets, lack of high fat/high sugar food, and lack of excess food and cigarettes. Despite this alcohol consumption was high in Kilimanjaro.

Data available indicate that, within populations the serum cholesterol and blood pressure levels of individual children and young people are significantly related to the dietary patterns. ${ }^{3}$ Most of the risk factors in our study are established before the age of 15 years. Hence there is need for health promotion on the avoidance of the risk factors of cardiovascular disease not only to parents but to school age children before age 15 once greater affluence and/or availability develop.

We are grateful to the British Council, ODA, British Diabetic Association, and World Health Organisation for financial support. We should also like to thank the staff of the Department of Clinical Biochemistry, Muhimbili Medical Centre and the Department of Medicine, University of Newcastle upon Tyne for invaluable laboratory support.

1 Kagan AR, Uemura K. Atherosclerosis of the aorta and coronary arteries in five towns. Bull World Health Organ 1976; 53: 489-500.

2 Tejada C, Strong JP, Montenegro MR, Restrepo C, Solberg LA. Distribution of coronary and aortic atherosclerosis by geographic location, race and sex. Lab Invest 1968; 18: geographi

3 WHO Expert Committee. Prevention in childhood and youth of adult cardiovascular diseases: time for action. youth of adult cardiovascular
WHO Tech Rep Ser 1990; 792.

4 Whincup PH, Cook DG, Shaper AG, MacFarlane DJ, Walker M. Blood pressure in British children: association with adult blood pressure and cardiovascular mortality. Lancet 1988, ii: 89-93.

5 Swai ABM, McLarty DG, Kitange HM, et al. Low prevalence of risk factors for coronary heart disease in rura Tanzania. Int $\mathcal{f}$ Epidemiol (in press.)

6 Shigan EN. Integrated programme for noncommunicable diseases pevention and control (NCD). World Health Stat $Q$ 1988; 41: 267-73.
7 Kitange H, Swai ABM. The Tanzanian WHO Interhealth project. Practical Diabetes Digest 1990; 1: 148-9.

8 WHO Expert Committee. Prevention of coronary heart disease. WHO Tech Rep Ser 1982; 678.

9 Clarke WR, Schrott HG, Leaverton PE, Connor WE, Lauer RM. Tracking of blood lipids and blood pressures in school age children: the Muscatine study. Circulation 1978; 58: 626-34.

10 Kannel WB, Castelli WP, Gordon T, McNamara PM Serum cholesterol, lipoproteins and the risk of coronary Serum cholesterol, lipoproteins and the risk of coronary 74: $1-12$.

11 Keys A. Coronary heart disease in seven countries. Circulation 1970; 41: suple 1: 1-200.

12 Chen Z, Peto R, Collins R, MacMahon S, Lu J, Li W. Serum choesterol concentration and coronary heart disease in population with low cholesterol concentrations. BMF 1991; 303: $276-82$.

13 Kannel WB, Dawber TR. Atherosclerosis as a pediatric problem. F Pediatr 1972; 80: 544-54.

14 Anderson LB, Henckel P, Saltin B. Risk factors for cardiovascular disease in 16-19 year old teenagers. F Intern Med 1989; 225: 157-63.

15 Hait HI, Lemeshow S, Rosenman KD. A longitudinal study of blood pressure in a national survey of children. $A m f$ of blood pressure in a national
Public Health 1982; 72: 1285-7.

16 Lauer RM, Connor WE, Leaverton PE, Reiter MA, Clark WR. Coronary heart disease risk factors in school children: the Muscatine study. $\mathcal{F}$ Pediatr 1975; 86: 697-706.

$17 \mathrm{Ng}$ 'Andu NH. Blood pressure levels of Zambian rural adolescents and their relationships to age, sex, weight, height and three weight-for-height indices. Int $\mathcal{F}$ Epidemio 1992; 21: 246-52.

18 Akinkugbe OO, Akinkugbe FM, Ayeni O, Solomon $\mathrm{H}$. Biracial study of arterial pressures in the first and second decades of life. BMF 1977; 1: 1132-4

19 Kleinman JC, Donahue RP, Harris MI, Finucane FF, Madans JH, Brock DB. Mortality among diabetics in a national sample. Am $\mathcal{f}$ Epidemiol 1988; 128: 389-401.

20 Kuller L, Perper J, Cooper M. Demographic characteristics and trends in arteriosclerotic heart disease mortality: and trends in arteriosclerotic heart disease mortality: sudden death and myoca
(Supple 3): III-1-III 15.

21 Chukwuemeka AC, Fulton WF, M'Ngola EN. Ischaemic heart disease among African diabetics in Nairobi. East Afr Med f 1972; 49: 854-9.

22 McLarty DG, Swai ABM, Mugusi F, Ramaiya K. The incidence of youth-onset diabetes in the African population of Dar es Salaam, Tanzania. Diabetic Med 1992; 9 (suppl 1): 43-44A.

23 McLarty DG, Swai ABM, Kitange HM, et al. Prevalence of diabetes and impaired glucose tolerance in rural Tanzania. diabetes and impaired

24 Swai ABM, McLarty DG, Kitange HM, et al. Study in Tanzania of impaired glucose tolerance: methodological myth? Diabetes 1991; 40: 516-20. 